\title{
A Guerra do Contestado: desfazendo as amarras do esquecimento
}

\section{Maria Cristina Ferreira dos Santos*}

\begin{abstract}
Resumo: Após a pesquisa de alguns monumentos e documentos que fazem parte da Memória Cultural da Guerra do Contestado das cidades de Canoinhas e Três Barras, na região Norte do estado de Santa Catarina, o objetivo, neste artigo, é discutir acerca dos motivos que contribuíram para a eclosão da guerra e, principalmente, descrever os possíveis motivos que levam esse acontecimento brutal a ser ocultado e esquecido. Para isso, relacionar-se-ão os relatos históricos e literários sobre a Guerra do Contestado, a saber, o romance de Walmor Santos e a obra de Maurício Vinhas de Queiroz aos conceitos de Jan Assmann, Paul Ricoeur e Sigmund Freud.
\end{abstract}

Palavras-chave: Guerra do Contestado; memória; esquecimento; trauma.

\begin{abstract}
After the research of the some monuments and documents that is part of the Cultural Memory of Contestado's War, of Canoinhas and Três Barras city, in the North of Santa Catarina state, the arm in this article is discuss about the reasons that contributed for the explosion of the war and, mainly, describe the possible reasons for this brutal event be hided and oblivion. For this, we will relate the historical narratives and literary about the Contestado War, that is, the novel of Walmor Santos and the work of Maurício Vinhas de Queiroz with the concepts of Jan Assmann, Paul Ricoeur and Sigmund Freud.
\end{abstract}

Keywords: Contestados' War; memory; oblivion; trauma.

Inúmeros fatores se amalgamam e, entrementes, se repelem, quando se pensa nos motivos que levaram à eclosão da Guerra do Contestado, uma das maiores e mais sangrentas revoltas camponesas da História da Humanidade que ocorreu, entre 1912 e 1916, em certas cidades do norte de Santa Catarina e sul do Paraná. No mapa vêem-se as terras contestadas bem como a estrada de ferro São Paulo - Rio Grande do Sul, que foi construída pela empresa Brazyl Railway, a qual gerou conflitos entre construtores e os donos das terras ocupadas, a saber, os sertanejos:

\footnotetext{
* Graduada em Letras Português/Espanhol e Português/Inglês pela Faculdade Estadual de Filosofia, Ciências e Letras de União da Vitória - PR, Especialista em Língua Portuguesa e Literaturas e Língua Espanhola pela mesma instituição. Mestranda em Literatura Brasileira pela Universidade Federal do Rio Grande do Sul.
} 


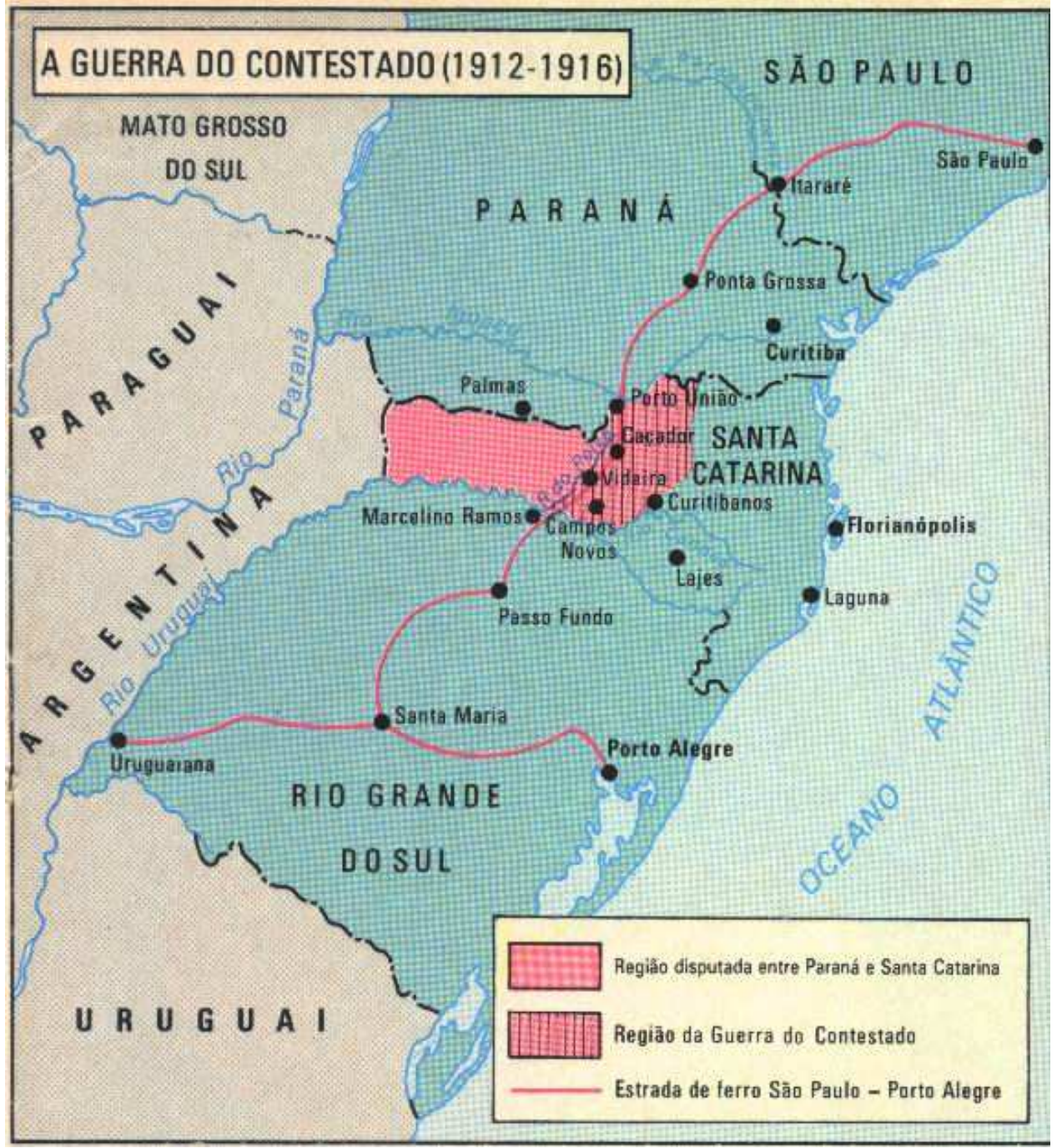

Fig. $1^{1}$

Conforme Walmor Santos (2009), um dos motivos primordiais é que os limites entre as províncias de São Paulo com Santa Catarina, até a eclosão da guerra, não haviam sido definidos. Com a Guerra dos Farrapos, no Rio Grande do Sul, entre os anos de 1835 a 1845, o governo imperial precisou romper a relação dos liberais gaúchos com os liberais paulistas e para isso houve a criação de uma nova província. Entretanto, apenas em 1853 houve a fundação da província do Paraná, sem a definição de limites precisos: "Esta é a raiz mais antiga da contestação de terras pelos estados do Paraná e de Santa Catarina" (SANTOS, 2009, p.22).

Outro motivo é que o povo da região contestada vivia em péssimas condições, sem qualquer assistência, pois com o fim do Império e com o advento da República, a situação

\footnotetext{
${ }^{1}$ Fonte:http://4.bp.blogspot.com/_cyvI1Ebw2fg/SxEA8AzYRtI/AAAAAAAAAyA/_sdMZSrbXM/s1600/Conte stado+Mapa.jpg
} 
piorou para os caboclos, principalmente com a instalação, em Três Barras, da empresa Southern Brazil Lumber \& Colonization, a maior companhia madeireira da América do Sul, que tinha como intuito explorar a araucária e a imbuia, as maiores riquezas da região. A Lumber comprou 180 mil hectares ao sul dos rios Negro e Iguaçu e expulsou inúmeros camponeses que lá residiam. Em dez horas de trabalho cortavam 1050 dúzias de tábuas, assim se praticou a primeira devastação ecológica industrialmente planejada da América Latina, com a derrubada de dois milhões de pinheiros nos quarenta anos de exploração.

Além disso, a construção da ferrovia São Paulo - Rio Grande do Sul, pela poderosa multinacional Brazil Railway, e a concessão governamental aos construtores de quinze quilômetros de cada lado da ferrovia para explorar madeira e erva-mate, fez com que muitos moradores fossem progressivamente desalojados, à força, durante anos.

Diante de tantos percalços, quando o monge João Maria passou pela região, encontrou um povo sedento de ajuda e, destarte, fez a promessa de construir uma cidade santa onde reinasse a paz e a abundância, e afirmou que todos os males eram oriundos da República, caracterizada, por ele, como o governo do demônio, e, dessa forma, os caboclos, para lograr o "paraíso" almejado, deviam lutar contra o governo e lutar pela volta do governo de Deus, a saber, o Regime Imperialista: “(...) encontravam-se desamparados pelo governo, que não criava escolas nem praticava a Justiça, e pela própria Igreja, com a ausência de capelas nos arraiais e de escolas com orientação religiosa. Outra não era a razão do fanatismo em torno dos monges" (SANTOS, 2009, p.79).

Conforme Maurício Vinhas de Queiroz (1981), após a morte de José Maria eclodiu a crença em sua ressurreição e os discípulos mais fiéis voltaram a reunir-se um ano depois, aguardando o seu místico retorno e a instauração na terra de um reinado de paz, justiça e fraternidade.

Todavia, no lugar da paz, da justiça e da fraternidade, a guerra transformou as cidades em ninhos de guerrilheiros, os quais vieram a multiplicar-se em redutos fortemente articulados, esparsos por grandes extensões de terras. Ademais, mulheres e homens eram espancados por infrações à fé: "Aos que não queriam se recrutar, garantiam que, por ordem de José Maria, os sertanejos tinham que declarar guerra ao governo e à polícia, aqueles que se recusassem haveriam de sofrer castigos sobrenaturais, como o de verem-se envolvidos em trevas por três dias" (SANTOS, 2009, p.137). Todos os contrários às convicções do monge, eram declarados hereges e estavam, dessarte, condenados a perder suas propriedades em favor da rebeldia. Esta era a famigerada "Santa Religião" de José Maria. 
Do lado dos defensores da República e dos defensores dos coronéis, os quais usurparam as terras daqueles camponeses que não tinham registros, a guerra foi um laboratório de experiências para o Exército Brasileiro, pois foram mobilizados dois terços do Exército Brasileiro, milícias estaduais e forças paranaenses. Foi um grande teste do exército moderno, porque, pela primeira vez na América Latina, utilizaram-se aviões com fins militares, bombas de fragmentação e aprimoradas técnicas de contra-insurgência, os quais apenas foram esboçados na Guerra de Canudos.

De ambos os lados imperou a barbárie, o que pode ser uma das justificativas para almejar o esquecimento de tão culposas lembranças.

\section{Textos culturais sobre a Guerra do Contestado}

Antes de discorrer acerca da política do esquecimento que paira sobre a região das terras contestadas, é mister elencar alguns dos monumentos, documentos e textos da Memória Cultural desta guerra. Conforme Jan Assmann (2008), os textos culturais são:

(...) todos los complejos de signos que possen una vinculación especialmente normativa y formativa para la sociedad en su conjunto asegurando su identidad y sentido. No se trata únicamente de textos, sino también de danzas, ritos, símbolos, etc. Los textos culturales pretenden vincular a toda la sociedad, determinan su identidad y coherencia, estructuran el mundo de sentido dentro del cual ella se comprende a si misma y también la conciencia de unidad, pertenencia y particularidad a través de cuya transmisión el grupo puede reproducir a lo largo de las generaciones y volver a reconocerse como tal (ASSMANN, 2008, p.165).

Em uma visita ao museu da cidade de Três Barras, denominado Museu do Contestado, vemos o amálgama de distintos elementos da guerra, a saber: fotos do monge, fotos de alguns administradores da Lumber e de seus familiares, fotos dos trabalhadores construindo a estrada de ferro, e uma foto do dialético Alemãozinho, que é uma figura curiosa da Guerra, pois foi desertor de uma canhoeira alemã aportada em São Francisco do Sul, percorreu uma vida de aventuras nas terras ensangüentadas do Planalto Catarinense e lutou pela causa dos rebeldes. Chegou a destruir o cartório de Itaiópolis, que fornecia escrituras das terras roubadas pelos coronéis e tornou-se comandante dos rebeldes, sendo logo destituído do cargo por desafetos. Como vingança, ele e mais duas centenas de rebeldes se entregaram às forças do general Setembrino declarando que deixaram de acreditar na Guerra, pois, nas suas concepções, o fanatismo não passava de banditismo. 


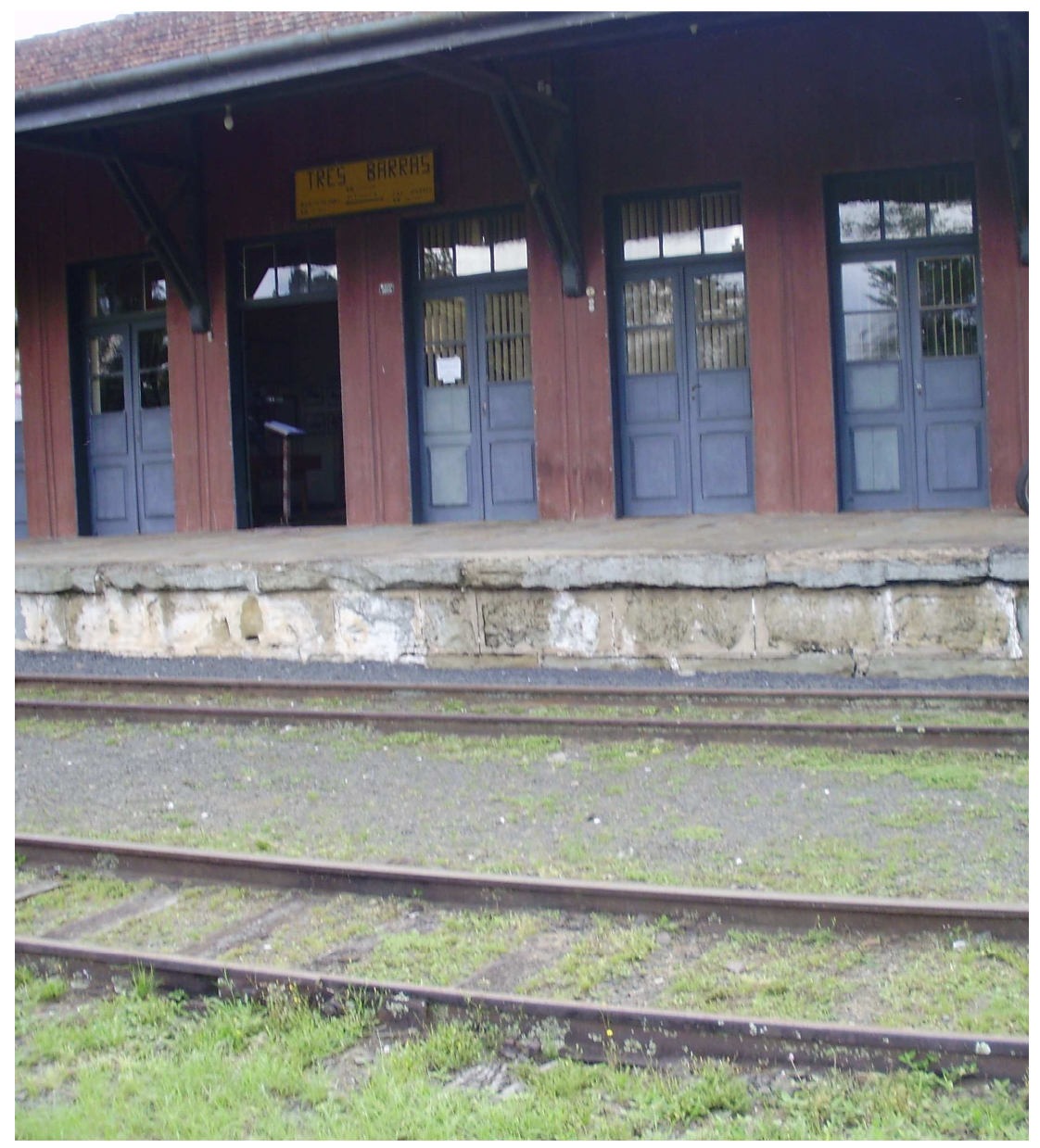

Fig. 2

(Museu do Contestado - Três Barras - SC)

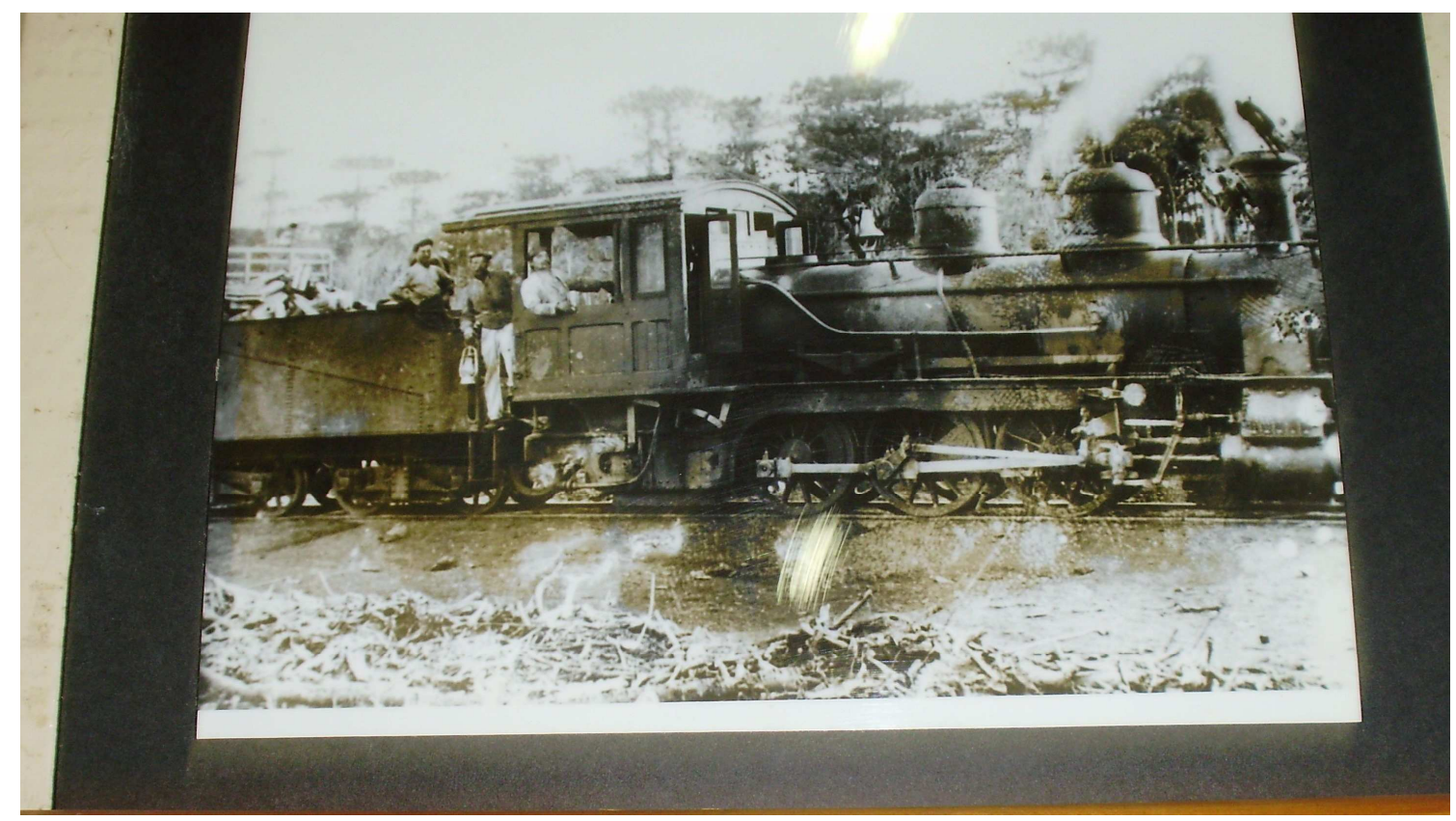

Fig.3

(Acervo do Museu de Três Barras - Trem na estrada de ferro que foi construída pelos sertanejos empregados da Lumber) 


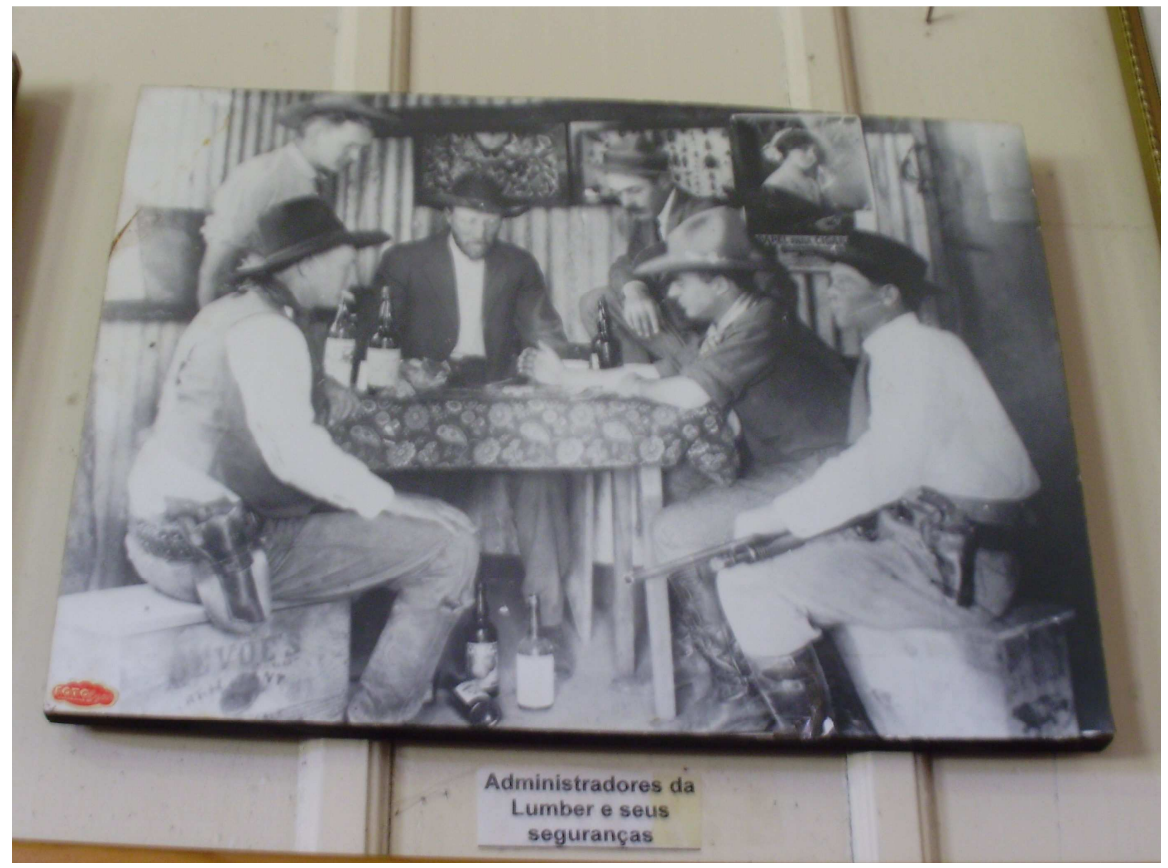

Fig.4

(Acervo do Museu do Contestado - Administradores da Lumber)

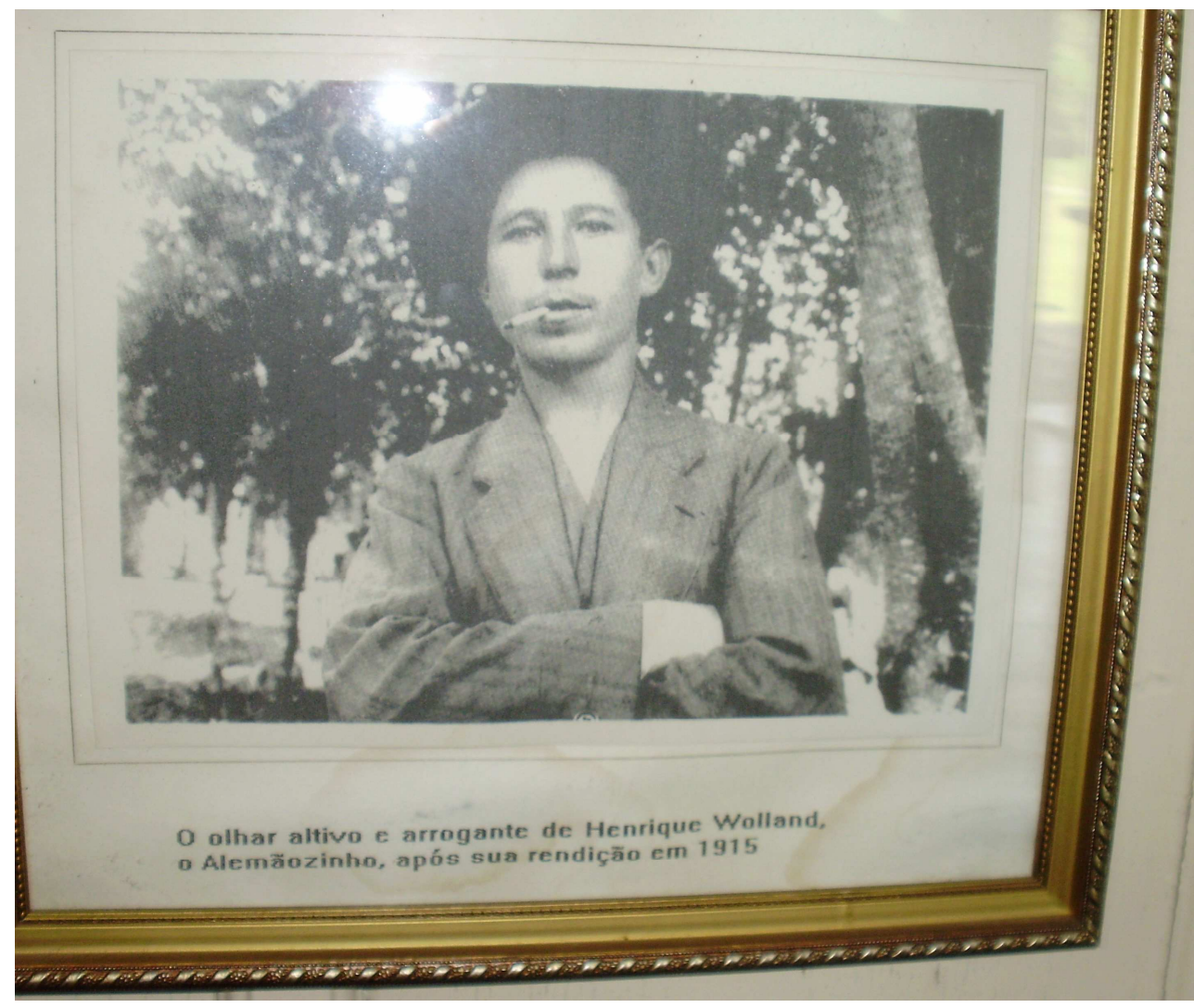

Fig.5

(Acervo do Museu do Contestado - Henrique Wolland, o Alemãozinho)

Em frente ao museu de Três Barras, há o terreno em que ficam as ruínas da antiga fábrica Lumber, e que hoje pertence ao Exército Brasileiro e abriga o Campo de Instrução. É 
uma demonstração da política do esquecimento e a demonstração de que a História é dialética posto que compreende uma luta infindável entre lembrar e esquecer, pois, de um lado, há o Museu conservando elementos da memória da guerra, de outro, o Exército, que dificulta a visita ao espaço que pertencera à Lumber, e onde há, ainda, conservada a sala de cinema, que, no início do século vinte, junto com o de Rio de Janeiro, era o único do Brasil, e conservados tantos outros elementos que, para o pesquisador, à maneira de um arqueólogo, são pequenos traços que ajudam a compor a labiríntica Memória Cultural da Guerra do Contestado.

A priori, as ruínas da Lumber podem ser visitadas e fotografadas, mas, para isso, é necessário um longo caminho análogo ao caminho que Josef K. percorreu em O Processo, na medida em que é preciso travar contato com inúmeros militares e fazer procedimentos burocráticos, o que demanda um tempo incomensurável.

Além do Museu de Três Barras, em que há textos culturais sobre a Guerra entre sertanejos e republicanos, no centro de Canoinhas há o Posto do Contestado, um posto de gasolina em que são exibidas, na parede da frente, várias fotos de trabalhadores da Lumber, fotos de alguns combates, foto das imbuias e a arquetípica foto do Contestado:

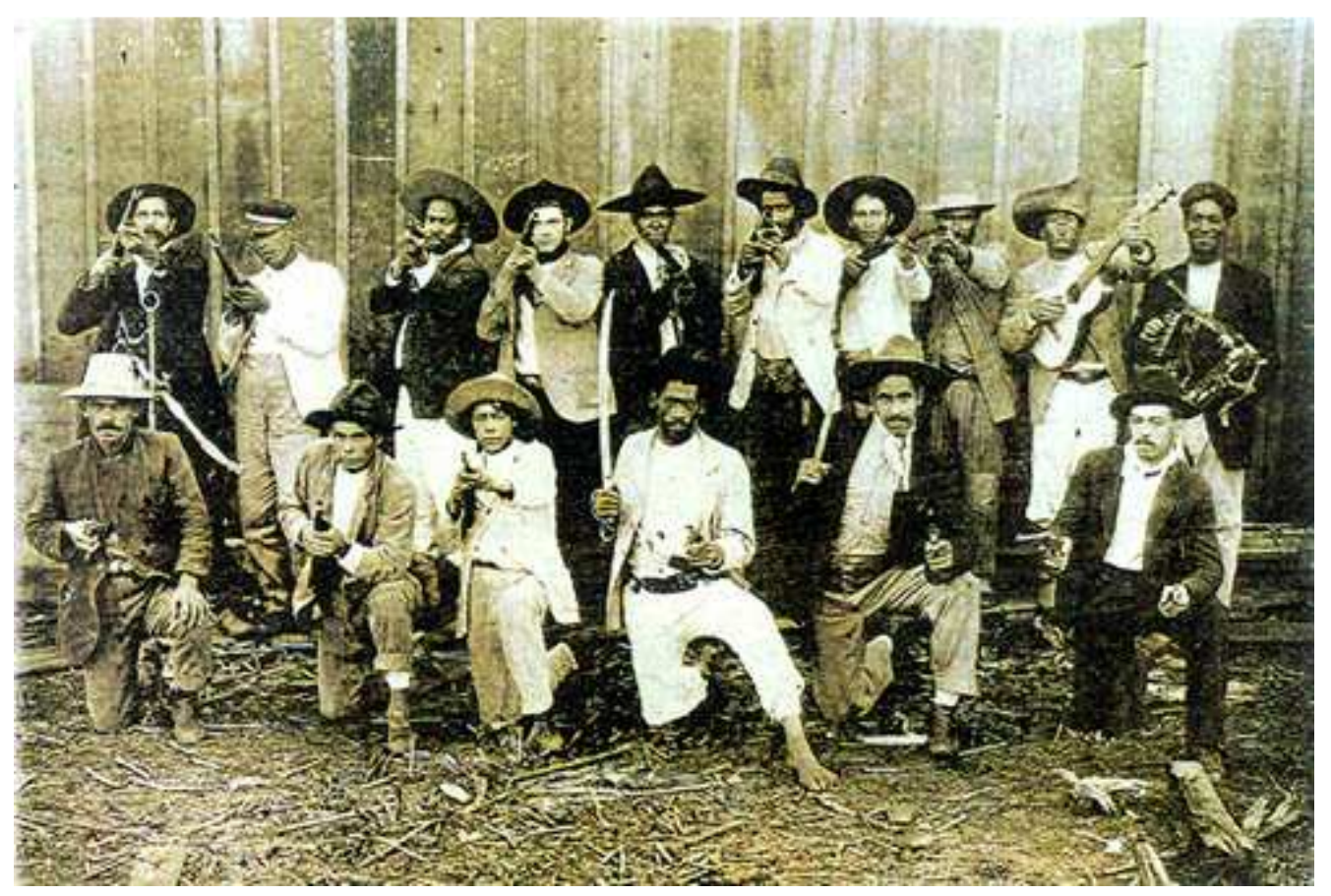

Fig.6

(Acervo de Josué Guimarães - Posto do Contestado, Canoinhas - SC)

Segundo o historiador de Canoinhas, Paulo Tokarski, autor de Cronografia do Contestado (2004), nesta foto arquetípica há uma espécie de equívoco de transmissão do legado, na medida em que é ressaltado, neste posto, no museu e em vários livros sobre a 
Guerra, que trata-se de fanáticos preparados para a luta, porém não são rebeldes sertanejos, mas sim vaqueanos, que, conforme Paulo Pinheiro Machado (2004), eram os que caçavam caboclos do mato, sendo pagos pelo número de orelhas que apresentavam.

Em frente ao museu de Canoinhas, que se dedica tão-somente às obras contemporâneas de artistas locais, há uma estátua, sem legenda, do monge João Maria:

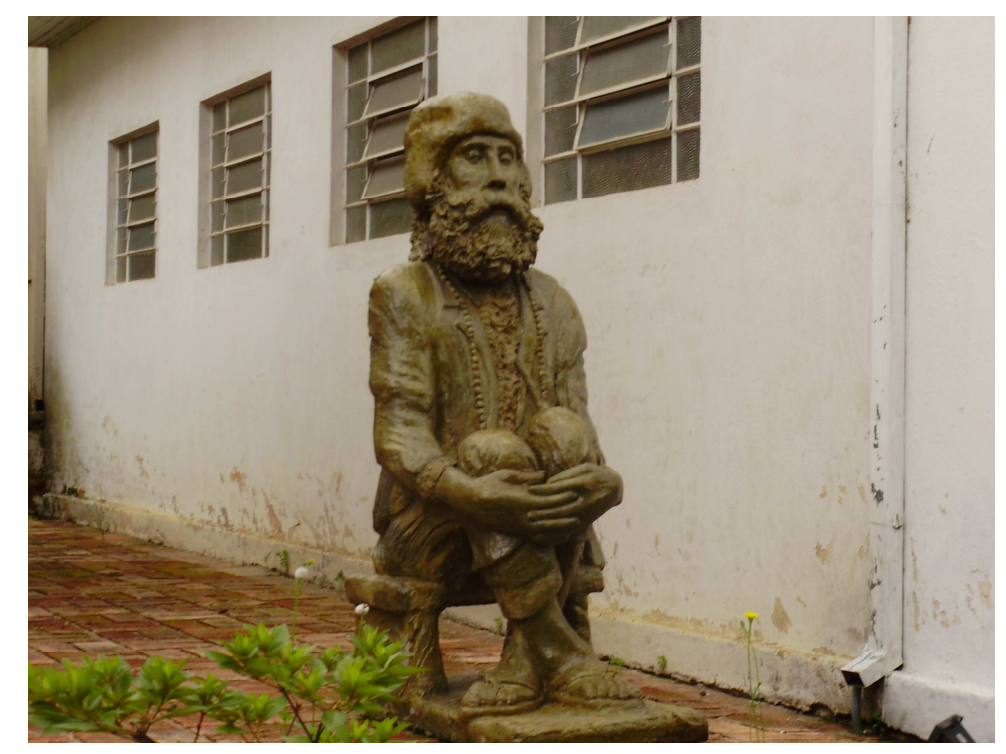

Fig.7

(Estátua do Monge, Museu de Canoinhas, SC)

Há, no Distrito de Paula Pereira, uma gruta onde fiéis fazem orações, levam oferendas e estabelecem promessas ao monge João Maria:

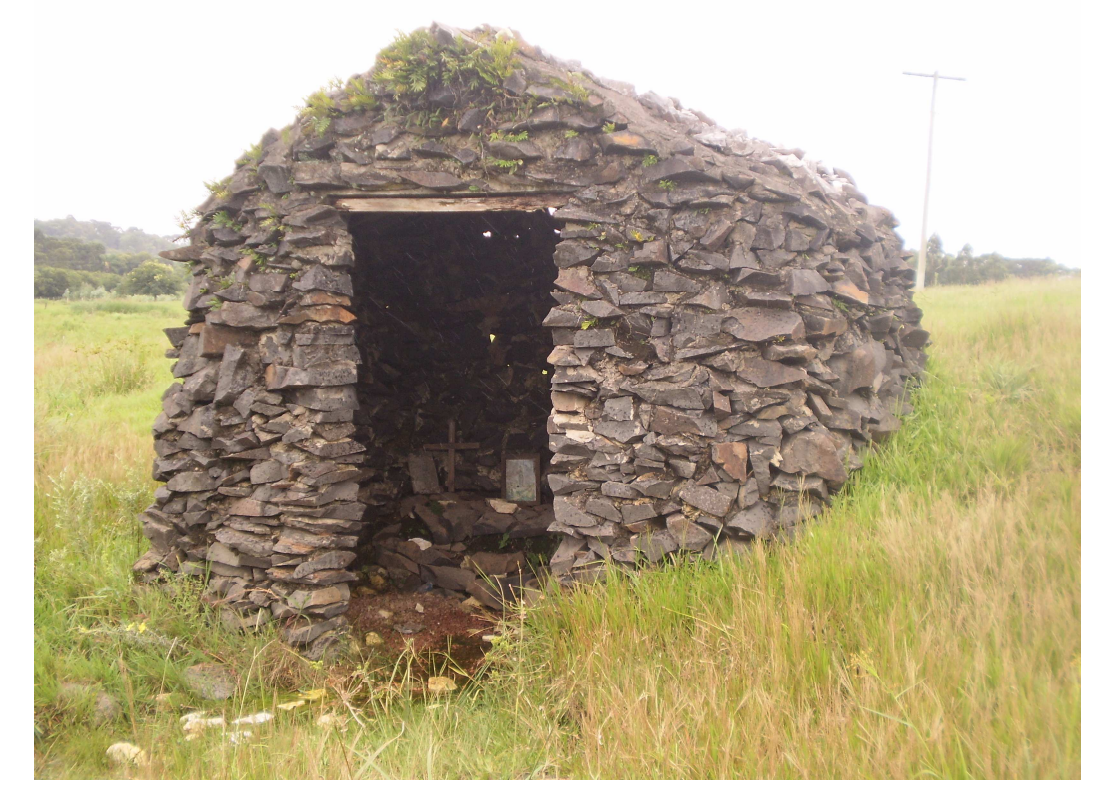

Fig. 8

(Gruta São João Maria, em Paula Pereira, SC) 


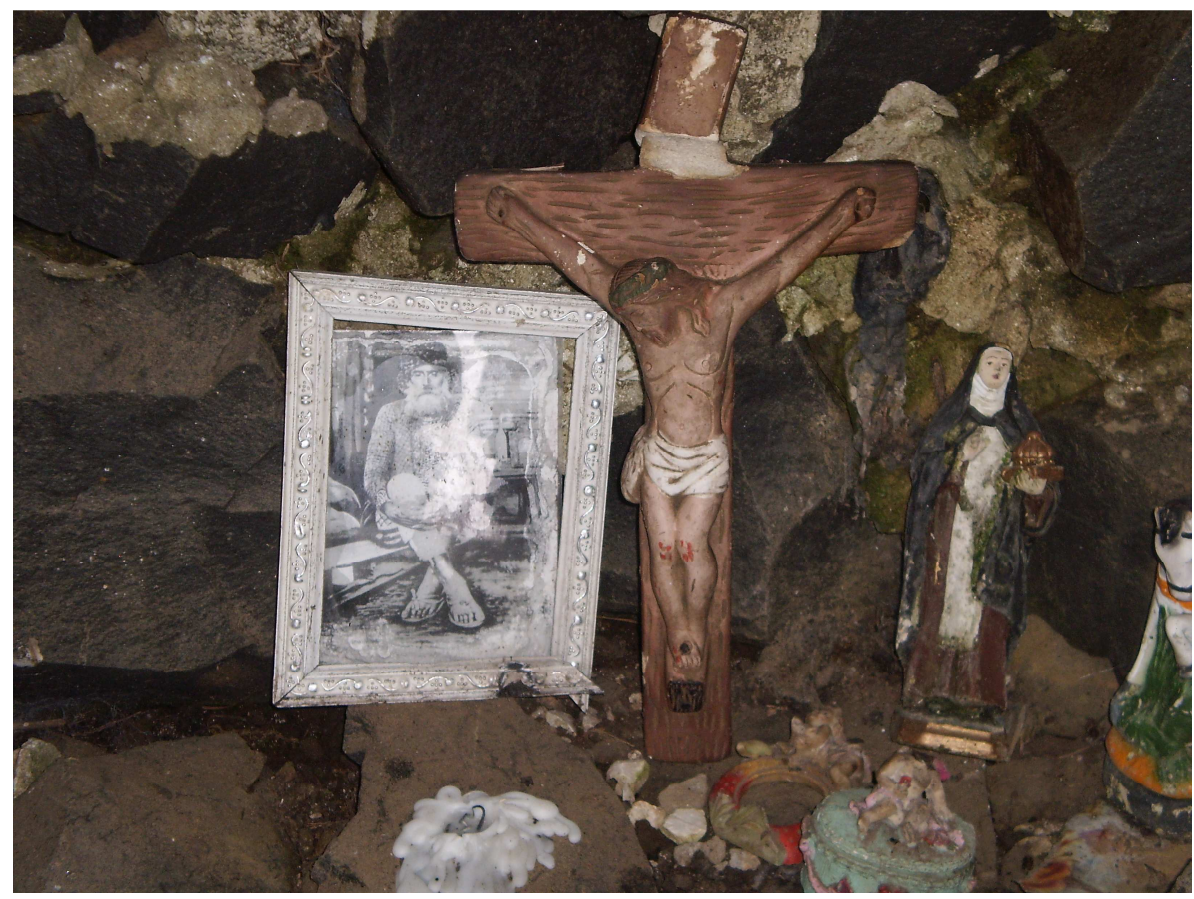

Fig.9

(Oferendas dos que crêem nos milagres do monge João Maria)

\section{Culpa, trauma e esquecimento}

Mais forte que os poucos elementos de Memória Cultural que asseguram a transmissão do legado do genocídio do Contestado, é a política do esquecimento que paira na região das terras contestadas e, ademais, aquém e além dela.

Em uma matéria da revista Super Interessante, intitulada "A guerra que o Brasil esqueceu”, Cláudio Ângelo (2000), admoesta:

Unidos pela fé, 20000 camponeses se insurgiram contra o Exército até serem massacrados, em 1915. Uma das rebeliões mais sangrentas do Brasil. O conflito, simultâneo à Primeira Guerra Mundial, foi esquecido pela imprensa da época e minimizado pelos livros de História. Ninguém sabe nem sequer quantos morreram. Podem ter sido 10000 ou 20000 (ANGELO, 2000).

Quando questionado sobre os motivos para o esquecimento da guerra, o historiador Fernando Tokarski redargue que isso se deve ao massacre e aos testes bélicos que o exército realizou, e, além disso, porque é, dessa forma, um capítulo traumático do passado que a grande maioria não percebe motivos profícuos para rememorá-lo, pois se sentem responsáveis e parcialmente culpados.

Em muitos anos de pesquisa, Tokarski foi ao encontro de inúmeros sobreviventes ou filhos de sobreviventes da guerra e muitos deles, não apenas se negaram a fornecer informações, como também negaram suas participações, ou a de seus parentes, no conflito. 
Outra forma de esquecimento é o já citado fato de que o terreno que o governo concedeu, em 1910, à Empresa Lumber, para que explorasse a imbuia, é hoje propriedade do Exército, o qual oculta ruínas, ou seja, os rastros não foram apagados, mas o caminho até eles é de difícil acesso.

Ambos os lados, os rebeldes e os republicanos e seus respectivos descendentes, desconhecem a maneira de lidar com esse passado. E são justamente essas contradições, essas exclusões, esses ocultamentos, esses traumas e esquecimentos apaziguados que compõem a Memória Cultural de um episódio histórico, pois, de acordo com Jan Assmann (2008): "La memoria cultural es compleja, pluralista y labiríntica, engloba una cantidad de memorias vinculantes e identidades plurales, distintas en tiempo y en espacio, y de esas tensiones y contradiciones extrae su dinámica propia" (ASSMANN, 2008, p.50).

Através dessa memória, o indivíduo pode dispor livremente das existências mnemônicas, como é o caso dos que pesquisam a Guerra do Contestado, e, dessa forma, ter oportunidade de se orientar no vasto espaço das recordações que são atravessadas pelo esquecimento, pois conforme Assmann (2008), recorremos aos arquivos da tradição cultural para reativá-los. Muito embora, no caso estudado, reativar memórias seja um trabalho deveras cauteloso porque o povo permanece de luto pelo acontecimento traumático, que, segundo Paul Ricoeur (2007), "O trabalho de luto é o custo do trabalho da lembrança" (RICOEUR, 2007, p.92). A Guerra do Contestado é uma ferida simbólica que está armazenada nos arquivos da memória coletiva, a qual pede cura.

A repulsa em recordar se deve a que o legado da Guerra do Contestado parece abarcar os três tipos de culpabilidade descritos por Paul Ricoeur (2007), a saber, a culpa política, que é a do cidadão que pertence ao mesmo corpo político que os criminosos; a culpa moral, daqueles que atuaram direta ou indiretamente para que o mal se concretizasse; e a culpa metafísica, dos que são solidários do fato de ser homem numa tradição trans-histórica do mal. Além disso, culpa gera trauma que, segundo Freud (1996), faz com que o portador de uma lembrança traumática busque evitar o desprazer que seria produzido pela liberação do reprimido.

No entanto, Paul Ricoeur (2007) aponta um viés positivo para o esquecimento, na medida em que, no devir da História, o que vir-a-ser prevalece sobre o acabado. $\mathrm{O}$ esquecimento cambia as lembranças e fornece ao passado a peculiaridade de estar, sempre, em ininterrupta dialética com o presente e com o futuro. No caso da Guerra do Contestado, a cada negação de uma lembrança, modifica-se a memória que se tinha e, assim, ela permanece viva. 
Ao evocar o esquecimento, ele não deveria ser em forma de cólera como são as lembranças da guerra catarinense e do sul do Paraná, mas, antes, dever-se-ia curar essas feridas simbólicas para que a rememoração não se convertesse em um desprazer. Dessa forma, é o perdão que entra na dinâmica complexa da Memória Cultural, ponto em que, conforme Ricoeur (2007), convergem a História, a memória e o esquecimento. O perdão interromperia a aparente linearidade da História e modificaria a forma de lembrar e de esquecer.

Á propósito do perdão, é possível relacionar uma das teses de Walter Benjamin sobre o conceito de história, na qual ele discorre acerca da redenção, aos motivos que há para evitar as rememorações sobre a Guerra do Contestado:

\footnotetext{
O cronista que narra os acontecimentos, sem distinguir entre os grandes e os pequenos, leva em conta a verdade de que nada do que um dia aconteceu pode ser considerado perdido para a história. Sem dúvida, somente a humanidade redimida poderá apropriar-se totalmente do seu passado. Isso quer dizer: somente para a humanidade redimida o passado é citável, em cada um de seus momentos. (BENJAMIN, 1994, p. 223).
}

Ainda não houve a redenção, por isso o intuito do olvido permanece, e persiste o ocultamento de muitas informações e de muitos textos culturais sobre a Guerra do Contestado, e pulsam, especialmente, as feridas simbólicas que pedem cura.

\section{Considerações Finais}

Aos que legaram reminiscências traumáticas da Guerra do Contestado, prevalece a vontade avassaladora do esquecimento. Entretanto, justamente por constituírem feridas simbólicas da Memória Cultural é que essas lembranças clamam por serem revisitadas, na medida em que quando se permanece no luto, o passado e o presente se quedam separados, mas quando o rememorar não é doloroso, a reconstrução do passado torna-se uma ressurreição do pretérito e, assim, as amarras do esquecimento são rompidas e, como o narrador de Em busca do tempo perdido, se descobre que, ao tentar esquecer, nos deparamos com uma memória interminável, posto que cada olvido confere à memória transformações e à História o ininterrupto vir-a-ser.

\section{Referências}

ANGELO, C. Guerra do Contestado: A guerra que o Brasil esqueceu. Revista Super Interessante, abril de 2000. Disponível em: http://super.abril.com.br/superarquivo/2000/conteudo_128118.shtml. Acesso em janeiro de 2010 .

ASSMANN, J. Religión y memoria cultural. Diez estudios. Buenos Aires: Limod, Libros de la Araucaria, 2008.

BENJAMIN, W. Magia e técnica, arte e política. 7 ed. São Paulo: Brasiliense, 1994. 
FREUD, S. Além do princípio do prazer. In: Obras psicológicas completas. Rio de Janeiro: Imago, 1996.

MACHADO, P.P. Lideranças do Contestado. Campinas: Editora da UNICAMP, 2004.

QUEIROZ, M.V. Messianismo e conflito social (A Guerra Sertaneja do Contestado: 1912-1916). 3 ed. São Paulo: Ática, 1981.

RICOUER, P. A memória, a história, o esquecimento. Campinas: Editora UNICAMP, 2007.

SANTOS, W. Contestado: A guerra dos equívocos. O poder da fé. Vol I. Rio de Janeiro: Record, 2009.

TOKARSKI, F. Cronografia do Contestado. Apontamentos históricos da região do Contestado e do Sul do Paraná. Florianópolis: IOESC, 2002. 